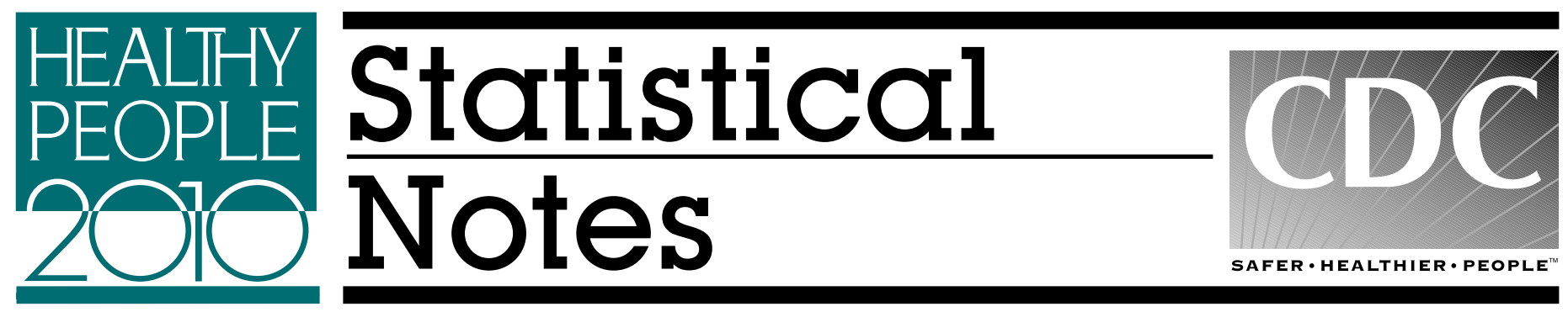

From the CENTERS FOR DISEASE CONTROL AND PREVENTION/National Center for Health Statistics

\title{
Age Adjustment Using the 2000 Projected U.S. Population
}

Richard J. Klein, M.P.H., and Charlotte A. Schoenborn, M.P.H.

\section{Introduction}

Age adjustment, using the direct method, is the application of observed age-specific rates to a standard age distribution to eliminate differences in crude rates in populations of interest that result from differences in the populations' age distributions. This adjustment is usually done when comparing two or more populations at one point in time or one population at two or more points in time. Age adjustment is particularly relevant when populations being compared have different age structures, for example, the U.S. white and Hispanic populations. The classic literature on age adjusting, ${ }^{1}$ as well as more recent National Center for Health Statistics (NCHS) publications, ${ }^{2-5}$ has focused on adjusting death rates and provides comprehensive discussions of age-adjustment techniques. However, age adjustment can be applied to any population-based event.

This report describes several sets of age-adjustment weights, based on the year 2000 projected U.S. population, that were used to generate age-adjusted baseline data for a number of Healthy People 2010 objectives. ${ }^{6}$ This work builds on the foundation set by the Department of Health and Human Services (DHHS), which established the year 2000 projected U.S. population as the standard population for age adjusting mortality statistics. The sets of weights provided in this paper use the age groupings most commonly found in existing DHHS publications. Age-adjustment weights, as well as examples of computer codes appropriate for calculating age-adjusted rates for complex sample surveys using the SUDAAN ${ }^{7}$ software package, are provided in this report. The weights and procedures shown are not intended as fixed rules for age adjustment, but rather as guidelines to promote and facilitate consistency and comparability in age-adjustment procedures among users of health-related data.

\section{Historical Perspective}

Several years ago, NCHS coordinated an effort that resulted in an agreement among certain Federal and State agencies to age adjust mortality data using the year 2000 projected U.S. population. ${ }^{3,4}$ In August 1998, the Secretary of the Department of Health and Human Services (DHHS)

\section{Acknowledgment}

The authors gratefully acknowledge the efforts of Virginia M. Freid (Division of Health and Utilization Analysis) who was a major contributor to the planning of this report and David A. Fessler (a summer intern with the Division of Health Promotion Statistics) who contributed substantially to the production of the data tables for this report.

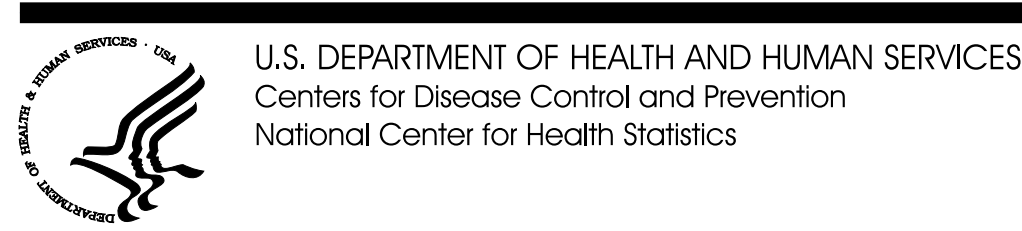


issued a policy statement directing all DHHS agencies to use the year 2000 projected U.S. population (hereafter referred to as the 2000 Standard Population) for age adjusting death rates beginning no later than data year $1999 .{ }^{8}$ This agreement resolved long-standing problems associated with the use of different standard populations for age adjusting death rates (U.S. 1940 population, U.S. 1970 population, U.S. 1980 population, etc.) by various agencies publishing mortality statistics, and the resultant difficulties experienced by data users in comparing these rates.

The decision to age adjust mortality data using the 2000 Standard Population focused on mortality data from the National Vital Statistics System and, therefore, was independent of other NCHS data systems (e.g., National Health Interview Survey, National Health and Nutrition Examination Survey, National Hospital Discharge Survey, National Nursing Home Survey, National Ambulatory Medical Care Survey, National Hospital Medical Care Survey, and National Hospice and Home Care Survey). Data for those systems have been age adjusted using a variety of standard populations such as 1970 U.S. civilian noninstitutionalized population and 1980 U.S. resident population, which can be found in appendix II of Health, United States, 1999. ${ }^{9}$ To improve comparability of ageadjusted rates among data systems, these data for NCHS surveys are being recalculated using the 2000 Standard Population in Health, United States, 2000 and Health, United States, 2001. In addition, beginning with 1999 data for the Chronic Disease Indicators, CDC will be producing age-adjusted data for States from the Behavioral Risk Factor Surveillance System using the 2000 Standard Population.

\section{Calculation of Age-Adjustment Weights: Background, Process, and Procedures}

The process of deriving age-adjustment weights for survey and other population-based data began by identifying age categories typically used for age adjustment and trying to ensure that all the various groupings could be constructed from a single "Master List" (table 1).

The source of the population figures in the Master List is the official Bureau of the Census projections for the year 2000 published in Current Population Reports, series P-25, no. 1130 , table $2^{10}$. It is the same publication on which the standard population for mortality data is based. ${ }^{4}$ The Census projections are disaggregated by sex and race. However, only the totals for both sexes and all races combined were used to develop the Master List. The complete 2000 population projections are available from the Bureau of the Census web site at: http://www.census.gov/prod/1/pop/p25-1130/p251130.pdf.

The Master List, consisting of 24 age groups, was developed to reduce discrepancies that can occur when extracting and combining numbers from the published Census projections. These projections for the 2000 population, both for single years of age and for 5-year age
Table 1. Master list: 2000 U.S. projected population and ageadjustment weights

\begin{tabular}{|c|c|c|}
\hline Age & $\begin{array}{l}\text { Population } \\
\text { in thousands }\end{array}$ & $\begin{array}{c}\text { Adjustment } \\
\text { weight }\end{array}$ \\
\hline All ages $\ldots \ldots \ldots \ldots \ldots$ & 274,634 & 1.000000 \\
\hline Under 1 year . . . . . . . . . . & 3,795 & 0.013818 \\
\hline 1 year. . . . . . . . . . . & 3,759 & 0.013687 \\
\hline $2-4$ years $\ldots \ldots \ldots \ldots \ldots$ & 11,433 & 0.041630 \\
\hline 5 years . . . . . . . . . . . & 3,896 & 0.014186 \\
\hline $6-8$ years $\ldots \ldots \ldots \ldots \ldots$ & 11,800 & 0.042966 \\
\hline 9 years . . . . . . . . . . . & 4,224 & 0.015380 \\
\hline $10-11$ years . . . . . . . . . . . & 8,258 & 0.030069 \\
\hline $12-14$ years . . . . . . . . . . . . . & 11,799 & 0.042963 \\
\hline 15-17 years . . . . . . . . . . . & 11,819 & 0.043035 \\
\hline $18-19$ years $\ldots \ldots \ldots \ldots \ldots$ & 8,001 & 0.029133 \\
\hline 20-24 years . . . . . . . . . . . . & 18,257 & 0.066478 \\
\hline 25-29 years . . . . . . . . . . . . & 17,722 & 0.064530 \\
\hline 30-34 years . . . . . . . . . . & 19,511 & 0.071044 \\
\hline 35-39 years . . . . . . . . . . . . & 22,180 & 0.080762 \\
\hline 40-44 years. . . . . . . . . . . . . & 22,479 & 0.081851 \\
\hline $45-49$ years . . . . . . . . . . . . & 19,806 & 0.072118 \\
\hline $50-54$ years . . . . . . . . . . . & 17,224 & 0.062716 \\
\hline $55-59$ years . . . . . . . . . . & 13,307 & 0.048454 \\
\hline $60-64$ years . . . . . . . . . . . & 10,654 & 0.038793 \\
\hline $65-69$ years . . . . . . . . . . . . & 9,410 & 0.034264 \\
\hline $70-74$ years . . . . . . . . . . . . & 8,726 & 0.031773 \\
\hline $75-79$ years . . . . . . . . . . . . . & 7,415 & 0.027000 \\
\hline $80-84$ years . . . . . . . . . . . . . & 4,900 & 0.017842 \\
\hline 85 years and over . . . . . . . . & 4,259 & 0.015508 \\
\hline
\end{tabular}

NOTE: When using the NCHS Master List to obtain additional age groups not shown in table 2 , the age-adjustment weights should be recalculated using the appropriate denominator and must add to 1 (see "Calculation of Age-Adjustment Weights: Background, Process, and Procedures").

groups, are rounded to thousands. However, population counts for the 5-year age groups were calculated by summing the unrounded counts for single years (unpublished) and then rounding that sum. As a consequence, published sums of the single years of age do not necessarily add to the published 5-year totals, and weights based on the published Census projections may be slightly different depending on whether single-year or 5-year age groups are combined to produce the weights. By defining the Master List as the starting point for deriving age-specific population estimates and age-adjustment weights, such discrepancies are minimized. Once the Master List was established, weights were computed for a number of commonly used age distributions. The weight for a given age group is the size of the corresponding age group in the standard population divided by the total standard population for all ages of interest.

Table 2 shows 22 different population age distributions used in calculating baseline data from various major data systems for the Healthy People 2010 objectives that use age adjustment. Major data systems are those that are responsible for tracking five or more Healthy People 2010 objectives. Table A lists the distributions that were used by the major data systems. Age Distributions \#4 and \#18 each appear in two different data system groups. The specific groupings used depend on the age groups covered by the objective and on the number of events included in the measure used for the objective. These groupings can be used as a general 
Table 2: Selected age distributions and age-adjustment weights based on the 2000 projected U.S. population

\begin{tabular}{|c|c|c|c|c|c|}
\hline Age & $\begin{array}{l}\text { Population } \\
\text { in thousands }\end{array}$ & $\begin{array}{c}\text { Adjustment } \\
\text { weight }\end{array}$ & Age & $\begin{array}{l}\text { Population } \\
\text { in thousands }\end{array}$ & $\begin{array}{c}\text { Adjustment } \\
\text { weight }\end{array}$ \\
\hline Distribution \#1 & & & Distribution \#2 & & \\
\hline All ages $\ldots \ldots \ldots \ldots$ & 274,634 & 1.000000 & All ages $\ldots \ldots \ldots \ldots \ldots$ & 274,634 & 1.000000 \\
\hline Under 1 year . . . . . . . . . & 3,795 & 0.013818 & Under 12 years . . . . . . . . . & 47,165 & 0.171738 \\
\hline $1-4$ years $\ldots \ldots \ldots \ldots \ldots$ & 15,192 & 0.055317 & $12-19$ years . . . . . . . . . . . & 31,619 & 0.115131 \\
\hline 5-14 years. . . . . . . . . . . & 39,977 & 0.145565 & 20-29 years . . . . . . . . . . . . & 35,979 & 0.131007 \\
\hline $15-24$ years . . . . . . . . . . . & 38,077 & 0.138646 & $30-39$ years $\ldots \ldots \ldots \ldots \ldots$ & 41,691 & 0.151806 \\
\hline 25-34 years . . . . . . . . . . & 37,233 & 0.135573 & $40-49$ years . . . . . . . . . . . . & 42,285 & 0.153968 \\
\hline 35-44 years . . . . . . . . . . & 44,659 & 0.162613 & $50-59$ years $\ldots \ldots \ldots \ldots \ldots$ & 30,531 & 0.111170 \\
\hline 45-54 years . . . . . . . . . . . & 37,030 & 0.134834 & $60-69$ years . . . . . . . . . . . . & 20,064 & 0.073057 \\
\hline $55-64$ years . . . . . . . . . . . & 23,961 & 0.087247 & $70-79$ years . . . . . . . . . . . & 16,141 & 0.058773 \\
\hline $65-74$ years . . . . . . . . . . . . & 18,136 & 0.066037 & 80 years and over . . . . . . . & 9,159 & 0.033350 \\
\hline 75-84 years . . . . . . . . . . . & 12,315 & 0.044842 & & & \\
\hline 85 years and over $\ldots \ldots \ldots$ & 4,259 & 0.015508 & & & \\
\hline Distribution \#3 & & & Distribution \#4 & & \\
\hline All ages $\ldots \ldots \ldots \ldots \ldots$ & 274,634 & 1.000000 & All ages $\ldots \ldots \ldots \ldots \ldots$ & 274,634 & 1.000000 \\
\hline Under 18 years . . . . . . . . . . & 70,783 & 0.257736 & Under 18 years $\ldots \ldots \ldots \ldots \ldots$ & 70,783 & 0.257736 \\
\hline $18-44$ years $\ldots \ldots \ldots \ldots \ldots$ & 108,150 & 0.393797 & 18-44 years . . . . . . . . . . . & 108,150 & 0.393797 \\
\hline $45-54$ years . . . . . . . . . . . & 37,030 & 0.134834 & $45-64$ years . . . . . . . . . . . & 60,991 & 0.222081 \\
\hline $55-64$ years . . . . . . . . . . & 23,961 & 0.087247 & $65-74$ years . . . . . . . . . . & 18,136 & 0.066037 \\
\hline $65-74$ years . . . . . . . . . . . & 18,136 & 0.066037 & 75 years and over . . . . . . . . & 16,574 & 0.060349 \\
\hline 75 years and over . . . . . . . . & 16,574 & 0.060349 & & & \\
\hline Distribution \#5 & & & Distribution \#6 & & \\
\hline 2 years and over . . . . . . . & 267,080 & 1.000000 & 2 years and over . . . . . . . & 267,080 & 1.000000 \\
\hline $2-5$ years $\ldots \ldots \ldots \ldots \ldots$ & 15,329 & 0.057395 & $2-17$ years. . . . . . . . . . & 63,229 & 0.236742 \\
\hline $6-11$ years. . . . . . . . . . . & 24,282 & 0.090917 & 18-44 years . . . . . . . . . . . . & 108,150 & 0.404935 \\
\hline $12-19$ years . . . . . . . . . . . & 31,619 & 0.118388 & $45-54$ years . . . . . . . . . . & 37,030 & 0.138647 \\
\hline 20-29 years . . . . . . . . . . . & 35,979 & 0.134712 & $55-64$ years $\ldots \ldots \ldots \ldots \ldots$ & 23,961 & 0.089715 \\
\hline 30-39 years . . . . . . . . . . . & 41,691 & 0.156099 & $65-74$ years . . . . . . . . . . . & 18,136 & 0.067905 \\
\hline $40-49$ years . . . . . . . . . . . . & 42,285 & 0.158323 & 75 years and over . . . . . . . . & 16,574 & 0.062056 \\
\hline $50-59$ years . . . . . . . . . . . & 30,531 & 0.114314 & & & \\
\hline $60-69$ years . . . . . . . . . . . & 20,064 & 0.075124 & & & \\
\hline $70-79$ years $\ldots \ldots \ldots \ldots \ldots$ & 16,141 & 0.060435 & & & \\
\hline 80 years and over $\ldots \ldots \ldots$ & 9,159 & 0.034293 & & & \\
\hline Distribution \#7 & & & Distribution \#8 & & \\
\hline 12 years and over $\ldots \ldots \ldots$ & 227,469 & 1.000000 & 18 years and over $\ldots \ldots \ldots$ & 203,851 & 1.000000 \\
\hline $12-19$ years . . . . . . . . . . . & 31,619 & 0.139004 & 18-24 years . . . . . . . . . . . . & 26,258 & 0.128810 \\
\hline 20-29 years . . . . . . . . . . . . . & 35,979 & 0.158171 & 25-44 years . . . . . . . . . . & 81,892 & 0.401725 \\
\hline 30-39 years . . . . . . . . . . & 41,691 & 0.183282 & $45-64$ years . . . . . . . . . . & 60,991 & 0.299194 \\
\hline $40-49$ years . . . . . . . . . . . . . & 42,285 & 0.185893 & 65 years and over . . . . . . . . & 34,710 & 0.170271 \\
\hline $50-59$ years . . . . . . . . . . . & 30,531 & 0.134221 & & & \\
\hline 60-69 years . . . . . . . . . . . & 20,064 & 0.088205 & & & \\
\hline $70-79$ years $\ldots \ldots \ldots \ldots \ldots$ & 16,141 & 0.070959 & & & \\
\hline 80 years and over $\ldots \ldots \ldots$ & 9,159 & 0.040265 & & & \\
\hline Distribution \#9 & & & Distribution \#10 & & \\
\hline 18 years and over $\ldots \ldots \ldots$ & 203,851 & 1.000000 & 18 years and over $\ldots \ldots \ldots$ & 203,851 & 1.000000 \\
\hline 18-24 years . . . . . . . . . . . & 26,258 & 0.128810 & 18-29 years . . . . . . . . . . . & 43,980 & 0.215746 \\
\hline 25-34 years . . . . . . . . . . & 37,233 & 0.182648 & 30-39 years . . . . . . . . . . & 41,691 & 0.204517 \\
\hline 35-44 years . . . . . . . . . . & 44,659 & 0.219077 & $40-49$ years . . . . . . . . . . . . & 42,285 & 0.207431 \\
\hline $45-64$ years . . . . . . . . . . . & 60,991 & 0.299194 & $50-59$ years . . . . . . . . . . . & 30,531 & 0.149771 \\
\hline \multirow[t]{3}{*}{65 years and over . . . . . . . . } & 34,710 & 0.170271 & $60-69$ years . . . . . . . . . . . & 20,064 & 0.098425 \\
\hline & & & $70-79$ years . . . . . . . . . . . & 16,141 & 0.079180 \\
\hline & & & 80 years and over $\ldots \ldots \ldots \ldots$ & 9,159 & 0.044930 \\
\hline Distribution \#11 & & & Distribution \#12 & & \\
\hline 20 years and over $\ldots \ldots \ldots \ldots$ & 195,850 & 1.000000 & 20 years and over $\ldots \ldots \ldots \ldots$ & 195,850 & 1.000000 \\
\hline 20-29 years . . . . . . . . . . . & 35,979 & 0.183707 & 20-39 years . . . . . . . . . . & 77,670 & 0.396579 \\
\hline 30-39 years . . . . . . . . . . . & 41,691 & 0.212872 & 40-59 years . . . . . . . . . . . . & 72,816 & 0.371795 \\
\hline $40-49$ years . . . . . . . . . . . . . & 42,285 & 0.215905 & 60 years and over . . . . . . . . & 45,364 & 0.231626 \\
\hline $50-59$ years . . . . . . . . . . & 30,531 & 0.155890 & & & \\
\hline $60-69$ years $\ldots \ldots \ldots \ldots \ldots$ & 20,064 & 0.102446 & & & \\
\hline $70-79$ years . . . . . . . . . . . & 16,141 & 0.082415 & & & \\
\hline 80 years and over . . . . . . . & 9,159 & 0.046765 & & & \\
\hline
\end{tabular}


Table 2: Selected age distributions and age-adjustment weights based on the 2000 projected U.S. population-Con.

\begin{tabular}{|c|c|c|c|c|c|}
\hline Age & $\begin{array}{c}\text { Population } \\
\text { in thousands }\end{array}$ & $\begin{array}{c}\text { Adjustment } \\
\text { weight }\end{array}$ & Age & $\begin{array}{l}\text { Population } \\
\text { in thousands }\end{array}$ & $\begin{array}{c}\text { Adjustment } \\
\text { weight }\end{array}$ \\
\hline Distribution \#13 & & & Distribution \#14 & & \\
\hline 20 years and over $\ldots \ldots \ldots \ldots$ & 195,850 & 1.000000 & 25 years and over $\ldots \ldots \ldots \ldots$ & 177,593 & 1.000000 \\
\hline 20-44 years . . . . . . . . . . . & 100,149 & 0.511356 & 25-34 years . . . . . . . . . . & 37,233 & 0.209654 \\
\hline $45-64$ years . . . . . . . . . . . & 60,991 & 0.311417 & 35-44 years . . . . . . . . . . & 44,659 & 0.251468 \\
\hline \multirow[t]{2}{*}{65 years and over $\ldots \ldots \ldots \ldots$} & 34,710 & 0.177227 & 45-64 years . . . . . . . . . . & 60,991 & 0.343431 \\
\hline & & & 65 years and over . . . . . . . . . & 34,710 & 0.195447 \\
\hline Distribution \#15 & & & Distribution \#16 & & \\
\hline 40 years and over $\ldots \ldots \ldots$ & 118,180 & 1.000000 & 45 years and over $\ldots \ldots \ldots$ & 95,701 & 1.000000 \\
\hline $40-49$ years . . . . . . . . . . . . & 42,285 & 0.357802 & $45-49$ years . . . . . . . . . . . & 19,806 & 0.206957 \\
\hline $50-64$ years . . . . . . . . . . . & 41,185 & 0.348494 & $50-64$ years . . . . . . . . . . & 41,185 & 0.430351 \\
\hline 65 years and over $\ldots \ldots \ldots \ldots$ & 34,710 & 0.293704 & 65 years and over . . . . . . . . . & 34,710 & 0.362692 \\
\hline Distribution \#17 & & & Distribution \#18 & & \\
\hline 50 years and over $\ldots \ldots \ldots$ & 75,895 & 1.000000 & 65 years and over $\ldots \ldots \ldots$ & 34,710 & 1.000000 \\
\hline $50-64$ years . . . . . . . . . . . & 41,185 & 0.542658 & 65-74 years . . . . . . . . . . . & 18,136 & 0.522501 \\
\hline 65 years and over $\ldots \ldots \ldots \ldots$ & 34,710 & 0.457342 & 75 years and over $\ldots \ldots \ldots \ldots$ & 16,574 & 0.477499 \\
\hline Distribution \#19 & & & Distribution \#20 & & \\
\hline Under 18 years $\ldots \ldots \ldots \ldots$ & 70,783 & 1.000000 & Under 65 years $\ldots \ldots \ldots \ldots$ & 239,924 & 1.000000 \\
\hline Under 5 years. . . . . . . . . . . . & 18,987 & 0.268242 & Under 18 years . . . . . . . . . . & 70,783 & 0.295022 \\
\hline $5-11$ years. . . . . . . . . . . & 28,178 & 0.398090 & $18-44$ years. . . . . . . . . . . . & 108,150 & 0.450768 \\
\hline $12-17$ years $\ldots \ldots \ldots \ldots \ldots$ & 23,618 & 0.333668 & $45-64$ years $\ldots \ldots \ldots \ldots \ldots$ & 60,991 & 0.254210 \\
\hline Distribution \#21 & & & Distribution \#22 & & \\
\hline $5-64$ years $\ldots \ldots \ldots \ldots \ldots$ & 220,937 & 1.000000 & 18-64 years $\ldots \ldots \ldots \ldots \ldots$ & 169,141 & 1.000000 \\
\hline $5-17$ years. . . . . . . . . . . . & 51,796 & 0.234438 & 18-24 years . . . . . . . . . . . . & 26,258 & 0.155243 \\
\hline $18-44$ years . . . . . . . . . . . . & 108,150 & 0.489506 & 25-34 years . . . . . . . . . . & 37,233 & 0.220130 \\
\hline $45-64$ years . . . . . . . . . . . & 60,991 & 0.276056 & 35-44 years . . . . . . . . . . . & 44,659 & 0.264034 \\
\hline & & & $45-64$ years. . . . . . . . . . . & 60,991 & 0.360593 \\
\hline
\end{tabular}

guide for researchers developing measures to track health variables. The actual choice of age groupings to be used for age adjusting, however, is an analytic decision and is, of course, not limited to the age distributions shown in table 2.

When creating the 22 age distributions shown in table 2, the age-specific population counts were constructed to be consistent with the published Census projections. In some cases, minor adjustments to the age-adjustment weights were necessary for the weights to sum to one. With the exception of Age Distribution \#1 (described below), age-specific counts for the age distributions shown in table 2 were derived directly from the Master List (table 1). The total population for each distribution was obtained by summing the component age-specific population counts. Age-adjustment weights for each of the age distributions were obtained by dividing the age-specific counts by the total population over all ages in that age distribution, rounding to six decimal places, and making any necessary adjustments (where the impact would be the least) so that the weights summed to 1 (rounded to six decimals places: 1.000000.) Note that regardless of whether the age distribution covers all ages or a subset of all ages (e.g., adults, children, elderly), the weights are renormalized to always sum to 1 .

Age Distribution \#1, shown in table 2, consists of age groups and age-adjustment weights previously published by the NCHS Division of Vital Statistics and used for age adjusting mortality statistics. ${ }^{4}$ An erratum sheet was published that shows the weight for the 75-84 year-old group as 0.044842 , instead of 0.044841 initially printed. This minor difference is an example of the adjustments that must be made to the actual weight for the weights to sum to 1 . The actual calculated weight was 0.044841498 , which when rounded to six decimal places, was 0.044841 . However, using this weight, the sum of all of the weights fell short of 1 . After making a minor modification that increased the weight to 0.044842 , the age-adjustment weights summed to 1 .

A similar procedure was used to obtain the weights for the five age distributions presented that required small adjustments so that the weights summed to 1 (see table B.) In all cases, the modification (either increasing or decreasing the sixth decimal place so that the weights would sum to 1) was made to the age group where the impact on the age-adjustment calculation would be the least. No modifications were required for any other age groups.

It should be noted that the number of age groups used for age adjusting may have a small impact on the level of the age-adjusted rate. For example, Age Distributions \#8 and \#9 in table 2 are both for adults 18 years and older. However, Age Distribution \#9 uses five age groups (providing more detail in the 25-44 year-old age group) while Age Distribution \#8 uses four age groups. Age adjustment using one of these distributions would yield slightly different estimates from the other.

In choosing the number of age groups for a specific analysis, two competing interests need to be addressed. First, 
Table A. Age distributions used by major Healthy People 2010 data systems

\begin{tabular}{|c|c|}
\hline Data systems & $\begin{array}{c}\text { Age distributions used } \\
\text { for Healthy People } 2010 \text { objectives }\end{array}$ \\
\hline NHIS, BRFSS, MEPS . . . . . . . . & $\# 3,6,8,9,14,15,16,17,18,19,22$ \\
\hline NHANES, CSFII . . . . . . . . & $\# 2,5,7,10,11,12$ \\
\hline NAMCS, NHAMCS. . . . . . . . . . & $\# 4,13$ \\
\hline NHDS. . . . . . . . . . . . & $\# 4,18,20,21$ \\
\hline 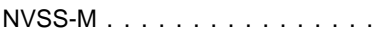 & \#1 \\
\hline
\end{tabular}

BRFSS is Behavioral Risk Factor Surveillance System.

CSFII is Continuing Survey of Food Intakes by Individuals.

MEPS is Medical Expenditure Panel Survey.

NAMCS is National Ambulatory Medical Care Survey.

NHAMCS is National Hospital Ambulatory Medical Care Survey.

NHANES is National Health and Nutrition Examination Survey.

NHDS is National Hospital Discharge Survey.

NHIS is National Health Interview Survey.

NVSS-M is National Vital Statistics System - Mortality.

the more age groups utilized, the tighter the control of the effect of the differences in the age distribution among groups or time periods being compared. On the other hand, when too many age groups are used and the data become sparse for certain age groups, the resultant age-specific rates used in the computation of the age-adjusted rate may have larger variances. It should also be noted that the greater the difference between the age distribution of the standard population used to age adjust (in this case, the 2000 Standard Population) and the age distribution of the study population, the greater the difference between the crude rate and the age-adjusted rate for the study population. When the age distribution of the standard population and the age distribution of the study population are the same, the crude rate is equal to the age-adjusted rate.

These 22 age distributions cannot cover all possible situations that would require age adjustment. Analysts desiring age breakouts not specified here can use the Master List to generate other age distributions and their associated age-adjustment weights. In some cases, the Master List may not contain all of the age groups desired. Additional detail, including age-sex-specific counts for use in age-sex adjustment, is available from the original Census population projections. ${ }^{10}$ When extracting additional subpopulations from the Census projections, the new standard population counts should be as consistent as possible with the Master List, and the weights of the newly constructed age distributions must sum to 1 .

\section{Age-Adjusted versus Crude Rates: Definitions and Examples}

Suppose that frequencies of the occurrence of a characteristic (e.g., being a current cigarette smoker) have been determined in each of several age groups for members of a study population (e.g., 1997 U.S. population, ages 18 years and older). These are age-specific frequencies of the characteristic (cigarette smoker). The age-specific rates of the characteristic are the ratios of the age-specific frequencies to the respective age-specific sizes of the study population.
Table B. Modifications to age-adjustment weights

\begin{tabular}{|c|c|c|c|}
\hline $\begin{array}{c}\text { Age } \\
\text { distribution }\end{array}$ & $\begin{array}{c}\text { Age } \\
\text { group }\end{array}$ & $\begin{array}{c}\text { Original } \\
\text { value }\end{array}$ & $\begin{array}{c}\text { Modified } \\
\text { value }\end{array}$ \\
\hline \#2 & 40-49 years & 0.153969 & 0.153968 \\
\hline \#6 & $45-54$ years & 0.138648 & 0.138647 \\
\hline \#7. & $50-59$ years & 0.134220 & 0.134221 \\
\hline \#15 & 65 years and older & 0.293705 & 0.293704 \\
\hline \#20 & Under 18 years & 0.295023 & 0.295022 \\
\hline
\end{tabular}

The crude rate of the characteristic is the total number of occurrences of the characteristic (cigarette smoker) across all age groups divided by the total study population (all persons ages 18 years and older). Age-specific and crude rates are often expressed as rates per 100 population (percents) or as rates per 1,000 or 100,000 population.

Suppose that population sizes for the same age groups have been obtained for a selected standard population. Then the age-adjusted rate of the characteristic is simply a weighted average of the age-specific rates. The weight for a given age group is the size of the corresponding age group in the standard population divided by the total standard population for all ages of interest. The weights thus add to 1 . The age-adjusted rate has the advantage (over the crude rate) of being controlled for age when compared to age-adjusted rates for other study populations that have different age structures. (Age-adjusted rates being compared must all be based on the same standard population.)

To illustrate, suppose one wants to examine smoking rates by level of education for people 18 years and older. Because the age distributions of various education groups differ, it is desirable to age adjust the rates to ensure that any education differences that are observed are not confounded by differences in the age structure of the various education groups. In this example, each education group (e.g., less than high school, high school graduate) is considered to be a separate study population, and the smoking rate for each is age adjusted. Examples of the calculation of age-adjusted smoking prevalence rates by level of education are shown in tables $\mathrm{C}$ and D. These tables illustrate two equivalent (except for differences caused by rounding) methods for calculating age-adjusted rates. Table $\mathrm{C}$ illustrates these calculations using the actual age-specific population frequencies from the 2000 Standard Population Age Distribution \#8 as weights. Table D illustrates these calculations using age-adjustment weights computed as the ratio of the age-specific population frequencies in the Standard Population Age Distribution \#8 to the total standard population in the age range covered. The age-adjustment weights in table $\mathrm{D}$ were rounded to six decimal places, but could have been rounded to any number with the possibility of slightly different results. Notice that the two methods yield identical results in percents shown to two decimal places.

\section{Application to Healthy People Objectives}

Age adjustment was used for most of the Healthy People 2000 objectives using mortality data, but only for a few selected other objectives. ${ }^{5}$ In Healthy People 2010, age 
Table C. Example of calculation of age-adjusted 1997 smoking prevalence among U.S. adults, by level of education, using 2000 Standard Population

\begin{tabular}{|c|c|c|c|c|c|c|}
\hline & $\begin{array}{l}1997 \text { NHIS } \\
\text { population } \\
\text { (weighted) }\end{array}$ & $\begin{array}{l}\text { Percent } \\
\text { smokers }\end{array}$ & $\begin{array}{l}\text { Number of } \\
\text { smokers }\end{array}$ & $\begin{array}{c}2000 \\
\text { Standard } \\
\text { Population }\end{array}$ & $\begin{array}{l}\text { Number of } \\
\text { smokers } \\
\text { (adjusted) }\end{array}$ & $\begin{array}{c}\text { Percent } \\
\text { smokers } \\
\text { (age adjusted) }\end{array}$ \\
\hline Education level and age & Column $A^{1}$ & Column $B^{2}$ & Column C & Column D & $\begin{array}{l}\text { Column } E^{3} \\
\text { (column B) } \\
\text { (column D) } \\
\end{array}$ & $\begin{array}{c}\text { Column F4 } \\
\text { (column E sum/ } \\
\text { column D sum) }\end{array}$ \\
\hline All education levels, 18 years and over ${ }^{5} \ldots \ldots \ldots \ldots$ & $193,844,144$ & 24.7 & $47,879,504$ & $203,851,000$ & $50,004,162$ & 24.53 \\
\hline 18-24 years . . . . . . . . . . . . . . . . . & $24,819,361$ & 28.7 & $7,123,157$ & $26,258,000$ & $7,536,046$ & \\
\hline 25-44 years . . . . . . . . . . . . . . . . . & $82,800,702$ & 28.6 & $23,681,001$ & $81,892,000$ & $23,421,112$ & \\
\hline $45-64$ years . . . . . . . . . . . . . . . . . . & $54,473,365$ & 24.4 & $13,291,501$ & $60,991,000$ & $14,881,804$ & \\
\hline 65 years and over $\ldots \ldots \ldots \ldots \ldots \ldots \ldots$ & $31,750,716$ & 12.0 & $3,810,086$ & $34,710,000$ & $4,165,200$ & \\
\hline All education levels, 18 years and over ${ }^{6} \ldots \ldots \ldots \ldots$ & $192,588,948$ & 24.5 & $47,655,050$ & $203,851,000$ & $50,029,822$ & 24.54 \\
\hline 18-24 years . . . . . . . . . . . . . . . . . & $24,738,889$ & 28.8 & $7,119,731$ & $26,258,000$ & $7,556,924$ & \\
\hline 25-44 years . . . . . . . . . . . . . . . . . . & $82,341,232$ & 28.6 & $23,531,470$ & $81,892,000$ & $23,403,088$ & \\
\hline $45-64$ years . . . . . . . . . . . . . . . . . . & $54,211,576$ & 24.4 & $13,228,268$ & $60,991,000$ & $14,882,528$ & \\
\hline 65 years and over $\ldots \ldots \ldots \ldots \ldots \ldots \ldots$ & $31,297,251$ & 12.1 & $3,775,581$ & $34,710,000$ & 4,187,282 & \\
\hline No high school diploma or GED, 18 years and over . . . . & $37,647,649$ & 30.5 & $11,482,533$ & $203,851,000$ & $69,188,135$ & 33.94 \\
\hline 18-24 years . . . . . . . . . . . . . . . . . & $5,556,522$ & 36.8 & $2,044,800$ & $26,258,000$ & $9,662,944$ & \\
\hline 25-44 years . . . . . . . . . . . . . . . . . . & $11,211,303$ & 41.1 & $4,607,846$ & $81,892,000$ & $33,657,612$ & \\
\hline $45-64$ years . . . . . . . . . . . . . . . . . . & $9,640,956$ & 34.9 & $3,364,694$ & $60,991,000$ & $21,285,859$ & \\
\hline 65 years and over $\ldots \ldots \ldots \ldots \ldots \ldots \ldots \ldots$ & $11,238,868$ & 13.2 & $1,483,531$ & $34,710,000$ & $4,581,720$ & \\
\hline GED, 18 years and over. $\ldots \ldots \ldots \ldots \ldots$ & $5,058,510$ & 48.8 & $2,468,553$ & $203,851,000$ & $91,893,718$ & 45.08 \\
\hline 18-24 years . . . . . . . . . . . . . . . . . & 685,628 & 66.7 & 457,314 & $26,258,000$ & $17,514,086$ & \\
\hline 25-44 years . . . . . . . . . . . . . . . . . & $2,681,175$ & 53.6 & $1,437,110$ & $81,892,000$ & $43,894,112$ & \\
\hline $45-64$ years . . . . . . . . . . . . . . . . . & $1,266,066$ & 39.0 & 493,766 & $60,991,000$ & $23,786,490$ & \\
\hline 65 years and over $\ldots \ldots \ldots \ldots \ldots \ldots \ldots \ldots$ & 425,641 & 19.3 & 82,149 & $34,710,000$ & $6,699,030$ & \\
\hline High school graduate, 18 years and over . . . . . . . . & $53,155,203$ & 28.7 & $15,255,543$ & $203,851,000$ & $59,055,709$ & 28.97 \\
\hline 18-24 years . . . . . . . . . . . . . . . . . . & $6,826,552$ & 31.4 & $2,143,537$ & $26,258,000$ & $8,245,012$ & \\
\hline 25-44 years . . . . . . . . . . . . . . . . . & $21,463,973$ & 35.5 & $7,619,710$ & $81,892,000$ & $29,071,660$ & \\
\hline $45-64$ years . . . . . . . . . . . . . . . . . . & $14,984,203$ & 28.7 & $4,300,466$ & $60,991,000$ & $17,504,417$ & \\
\hline 65 years and over $\ldots \ldots \ldots \ldots \ldots \ldots \ldots \ldots$ & $9,880,475$ & 12.2 & $1,205,418$ & $34,710,000$ & $4,234,620$ & \\
\hline Some college or higher, 18 years and over . . . . . . . & $96,727,586$ & 19.0 & $18,378,241$ & $203,851,000$ & $37,256,535$ & 18.28 \\
\hline 18-24 years . . . . . . . . . . . . . . . . . . & $11,670,187$ & 21.2 & $2,474,080$ & $26,258,000$ & $5,566,696$ & \\
\hline 25-44 years . . . . . . . . . . . . . . . . . & $46,984,781$ & 21.0 & $9,866,804$ & $81,892,000$ & $17,197,320$ & \\
\hline $45-64$ years . . . . . . . . . . . . . . . . & $28,320,351$ & 17.9 & $5,069,343$ & $60,991,000$ & $10,917,389$ & \\
\hline 65 years and over . . . . . . . . . . . . . . . & $9,752,267$ & 10.3 & $1,004,484$ & $34,710,000$ & $3,575,130$ & \\
\hline
\end{tabular}

\section{Standard Population: Distribution \#8}

Ages 18 years and over . . . . . . . . . . . .

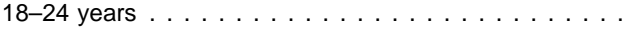
25-44 years . . . . . . . . . . . . . . .

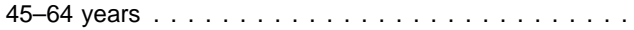
65 years and over. . . . . . . . . . . . .

\begin{tabular}{c}
$\begin{array}{c}\text { Standard } \\
\text { population } \\
\text { (in thousands) }\end{array}$ \\
\hline $\mathbf{2 0 3 , 8 5 1}$ \\
26,258 \\
81,892 \\
60,991 \\
34,710
\end{tabular}

Adjustment weight

$\mathbf{1 . 0 0 0 0 0 0}$

0.128810

0.401725

0.299194

0.170271

NOTE: For purposes of age adjusting, each education level can be considered a "study population."

${ }^{1}$ Excludes persons with unknown smoking status.

${ }^{2}$ Percents in this table should be entered into formulas as proportions, e.g., $24.7 \%=0.247$.

${ }^{3}$ Multiply the rate for each age-education-specific group (excluding 18 years and over) in column B by the standard population for the appropriate age group (column D) to get the age-adjusted frequency for each age group (column E). The 18 years and over frequencies are the sums of the age-specifc frequencies.

${ }^{4}$ For each education level, sum the four age-adjusted frequencies (column E) to get the total age-adjusted frequency for ages 18 years and over. Divide that sum by the total standard population 18 years and over to get the age-adjusted rate for that education level and multiply by 100 to express the rate as a percent (column F).

${ }^{5}$ Includes persons with unknown education status.

${ }^{6}$ Excludes persons with unknown education status.

adjustment was also used for most of the objectives using mortality data. However, the use of age adjustment was expanded to include many other Healthy People 2010 objectives that measure health outcomes and risk factors. In Healthy People 2010, age-adjusted data are shown for objectives and population subgroups that include either all ages or a wide range of ages. Objectives or population subgroups that include groups with relatively narrow age ranges (generally less than 40 years) are not adjusted.

For some population groups, age-adjusted rates are considerably different from crude rates. This occurs because the population distribution of the group is quite different 
Table D. Example of calculation of age-adjusted 1997 smoking prevalence among U.S. adults, by level of education, using ageadjustment weights based on the 2000 Standard Population

\begin{tabular}{|c|c|c|c|c|c|c|}
\hline & $\begin{array}{l}1997 \text { NHIS } \\
\text { population }\end{array}$ & $\begin{array}{l}\text { Percent } \\
\text { smokers }\end{array}$ & $\begin{array}{l}\text { Number of } \\
\text { smokers }\end{array}$ & $\begin{array}{c}\text { Age- } \\
\text { adjustment } \\
\text { weight } \\
\text { (2000 Standard } \\
\text { Population) }\end{array}$ & $\begin{array}{l}\text { Adjustment } \\
\text { factor }\end{array}$ & $\begin{array}{l}\text { Percent } \\
\text { smokers } \\
\text { (age } \\
\text { adjusted) }\end{array}$ \\
\hline Education level and age & Column $A^{1}$ & Column $B^{2}$ & $\begin{array}{l}\text { Column C } \\
\text { (column A) } \\
\text { (column B) }\end{array}$ & Column D & $\begin{array}{l}\text { Column } E^{3} \\
\text { (column B) } \\
\text { (column D) }\end{array}$ & $\begin{array}{c}\text { Column } \\
\text { (column E sum } \\
\text { expressed as } \\
\text { a percent) }\end{array}$ \\
\hline All education levels, 18 years and over ${ }^{5} \ldots \ldots \ldots \ldots$ & $193,844,144$ & 24.7 & $47,879,504$ & 1.000000 & 0.245297 & 24.53 \\
\hline 18-24 years . . . . . . . . . . . . . . . . . . & $24,819,361$ & 28.7 & $7,123,157$ & 0.128810 & 0.036968 & \\
\hline 25-44 years . . . . . . . . . . . . . . . . & $82,800,702$ & 28.6 & $23,681,001$ & 0.401725 & 0.114893 & \\
\hline $45-64$ years $\ldots \ldots \ldots \ldots \ldots \ldots \ldots \ldots \ldots$ & $54,473,365$ & 24.4 & $13,291,501$ & 0.299194 & 0.073003 & \\
\hline 65 years and over $\ldots \ldots \ldots \ldots \ldots \ldots \ldots$ & $31,750,716$ & 12.0 & $3,810,086$ & 0.170271 & 0.020433 & \\
\hline All education levels, 18 years and over ${ }^{6} \ldots \ldots \ldots \ldots$ & $192,588,948$ & 24.5 & $47,655,050$ & 1.000000 & 0.245424 & 24.54 \\
\hline 18-24 years . . . . . . . . . . . . . . . . . & $24,738,889$ & 28.8 & $7,119,731$ & 0.128810 & 0.037071 & \\
\hline 25-44 years . . . . . . . . . . . . . . . . & $82,341,232$ & 28.6 & $23,531,470$ & 0.401725 & 0.114805 & \\
\hline $45-64$ years $\ldots \ldots \ldots \ldots \ldots \ldots \ldots \ldots \ldots$ & $54,211,576$ & 24.4 & $13,228,268$ & 0.299194 & 0.073007 & \\
\hline 65 years and over $\ldots \ldots \ldots \ldots \ldots \ldots \ldots$ & $31,297,251$ & 12.1 & $3,775,581$ & 0.170271 & 0.020541 & \\
\hline No high school diploma or GED, 18 years and over . . . . & $37,647,649$ & 30.5 & $11,482,533$ & 1.000000 & 0.339406 & 33.94 \\
\hline 18-24 years . . . . . . . . . . . . . . . . . & $5,556,522$ & 36.8 & $2,044,800$ & 0.128810 & 0.047402 & \\
\hline 25-44 years . . . . . . . . . . . . . . . . & $11,211,303$ & 41.1 & $4,607,846$ & 0.401725 & 0.165109 & \\
\hline $45-64$ years $\ldots \ldots \ldots \ldots \ldots \ldots \ldots \ldots \ldots$ & $9,640,956$ & 34.9 & $3,364,694$ & 0.299194 & 0.104419 & \\
\hline 65 years and over $\ldots \ldots \ldots \ldots \ldots \ldots \ldots$ & $11,238,868$ & 13.2 & $1,483,531$ & 0.170271 & 0.022476 & \\
\hline GED, 18 years and over. . . . . . . . . . . . . & $5,058,510$ & 48.8 & $2,468,553$ & 1.000000 & 0.450789 & 45.08 \\
\hline 18-24 years . . . . . . . . . . . . . . . . . & 685,628 & 66.7 & 457,314 & 0.128810 & 0.085916 & \\
\hline 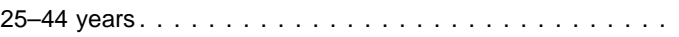 & $2,681,175$ & 53.6 & $1,437,110$ & 0.401725 & 0.215325 & \\
\hline $45-64$ years $\ldots \ldots \ldots \ldots \ldots \ldots \ldots \ldots \ldots$ & $1,266,066$ & 39.0 & 493,766 & 0.299194 & 0.116686 & \\
\hline 65 years and over $\ldots \ldots \ldots \ldots \ldots \ldots \ldots$ & 425,641 & 19.3 & 82,149 & 0.170271 & 0.032862 & \\
\hline High school graduate, 18 years and over . . . . . . . . & $53,155,203$ & 28.7 & $15,255,543$ & 1.000000 & 0.289700 & 28.97 \\
\hline 18-24 years . . . . . . . . . . . . . . . . . & $6,826,552$ & 31.4 & $2,143,537$ & 0.128810 & 0.040446 & \\
\hline 25-44 years . . . . . . . . . . . . . . . . & $21,463,973$ & 35.5 & $7,619,710$ & 0.401725 & 0.142612 & \\
\hline $45-64$ years $\ldots \ldots \ldots \ldots \ldots \ldots \ldots \ldots \ldots$ & $14,984,203$ & 28.7 & $4,300,466$ & 0.299194 & 0.085869 & \\
\hline 65 years and over $\ldots \ldots \ldots \ldots \ldots \ldots$ & $9,880,475$ & 12.2 & $1,205,418$ & 0.170271 & 0.020773 & \\
\hline Some college or higher, 18 years and over . . . . . . . . & $96,727,586$ & 19.0 & $18,378,241$ & 1.000000 & 0.182764 & 18.28 \\
\hline 18-24 years . . . . . . . . . . . . . . . . . & $11,670,187$ & 21.2 & $2,474,080$ & 0.128810 & 0.027308 & \\
\hline 25-44 years . . . . . . . . . . . . . . . . & $46,984,781$ & 21.0 & $9,866,804$ & 0.401725 & 0.084362 & \\
\hline $45-64$ years $\ldots \ldots \ldots \ldots \ldots \ldots \ldots \ldots \ldots$ & $28,320,351$ & 17.9 & $5,069,343$ & 0.299194 & 0.053556 & \\
\hline 65 years and over $\ldots \ldots \ldots \ldots \ldots \ldots \ldots$ & $9,752,267$ & 10.3 & $1,004,484$ & 0.170271 & 0.017538 & \\
\hline
\end{tabular}

\section{Standard Population: Distribution \#8}

Ages 18 years and over . . . . . . . . . . . . . 18-24 years . . . . . . . . . . . . . . . . . . . . . . . . . . . . . .

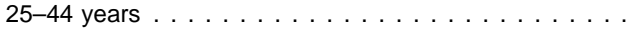
$45-64$ years $\ldots \ldots \ldots \ldots \ldots \ldots \ldots$ 65 years and over. . . . . . . . . . . . . . . . .

\begin{tabular}{|c|c|}
\hline $\begin{array}{c}\text { Standard } \\
\text { population } \\
\text { (in thousands) }\end{array}$ & $\begin{array}{c}\text { Adjustment } \\
\text { weight }\end{array}$ \\
\hline 203,851 & 1.000000 \\
\hline 26,258 & 0.128810 \\
\hline 81,892 & 0.401725 \\
\hline 60,991 & 0.299194 \\
\hline 34,710 & 0.170271 \\
\hline
\end{tabular}

NOTE: For purposes of age adjusting, each education level can be considered a "study population."

${ }^{1}$ Excludes persons with unknown smoking status.

${ }^{2}$ Percents in this table should be entered into formulas as proportions, e.g., $24.7 \%=.247$.

${ }^{3}$ Multiply the rate for each age-education-specific group (excluding 18 years and over) in column $\mathrm{B}$ by the age-adjustment weight for the appropriate standard age group (column $\mathrm{D}$ ) to get the adjustment factor for each age group (column E). The 18 years and over age adjustment factors are the sums of the age-specific adjustment factors.

${ }^{4}$ For each education level, sum the four age-specific adjustment factors (column E) to get the total age-adjusted rate for that education level and multiply by 100 to express the rate as a percent (column F).

${ }^{5}$ Includes persons with unknown education status.

${ }^{6}$ Excludes persons with unknown education status. 
Figure 1. SUDAAN code to produce age-adjusted rates using 2000 Standard Population figures (in thousands)

PROC DESCRIPT;

NEST

WEIGHT

VAR

CATLEVEL

STDVAR AGEGRP8 ;

$\begin{array}{lllll}\text { STDWGT } & 26258 & 81892 & 60991 & 34710\end{array}$

SUBGROUP

LEVELS

TABLES

\section{Age Adjustment Using SUDAAN Software}

When analyzing data from complex sample surveys (e.g., National Health Interview Survey, National Health and Nutrition Examination Survey), the sample design must be taken into account. SUDAAN, software for the statistical analysis of correlated data, is often used to calculate variance estimates for NCHS and other survey data. SUDAAN is specifically designed for analysis of cluster-correlated data from studies involving recurrent events, longitudinal data, repeated measures, multivariate outcomes, multistage sample designs, stratified designs, unequally weighted data, and without-replacement samples. SUDAAN fits marginal or population-averaged models using generalized estimating equations (GEE). Robust variance estimates are computed that fully account for intracluster correlation, unequal weighting, stratification, and without-replacement samples. This section provides SUDAAN code that can be used to age adjust survey data. More information on SUDAAN can be found at http://www.rti.org/patents/sudaan/sudaan.html.

Either age-specific population frequencies or the age-specific weights shown in table 2 (or derived from the Master List) may be used as weights to produce ageadjusted rates using SUDAAN's PROC DESCRIPT procedure. All of the calculations shown in tables $\mathrm{C}$ and $\mathrm{D}$ can be accomplished with just two lines of SUDAAN code added to the existing PROC DESCRIPT code.

Figure 1 shows PROC DESCRIPT code using standard population Age Distribution \#8 from table 2. The example variable (AGEGRP8) is a recode based on all ages of National Heath Interview Survey sample adults and consists of the following four age categories: 18-24 years, 25-44 years, 45-64 years, and 65 years and over. The numbers shown after the word STDWGT represent the number of persons in each of these age categories in the 2000 Standard Population, rounded to the nearest thousand. The age groupings of AGEGRP8 and the age groupings of the standard population (Age Distribution \#8) must match. SUDAAN uses the age-specific population frequencies to calculate the age-adjustment weights and then produces an age-adjusted rate for the total adult population, ages 18 and older.

Figure 2 shows PROC DESCRIPT code using the same variable as above (AGEGRP8) and the same four age categories: 18-24 years, 25-44 years, 45-64 years, and 65 years and older. However, instead of the age-specific standard population frequencies shown in the STDVAR statement in figure 1, this version uses the age-adjustment weights. These age-adjustment weights are the proportion each group represents of the total standard population ages 18 and older (rounded to six decimals) and correspond to the categories of the AGEGRP8 variable on the data file (i.e., ages 18-24 (0.128810), ages $25-44$ years (0.401725), ages $45-64(0.299194)$, and 65 years and older (0.170271).

The standard population age groupings must match those of the study population. For some survey data, 
adjustment to the total population (i.e., all ages) is appropriate. In other cases, such as the example used here, subsets of the all-ages population are the appropriate standard (e.g., persons 18 years and older for the NHIS Sample Adult questionnaire). It should be kept in mind that in some cases, the 2000 Standard Population may not be the most appropriate standard, such as in studies of populations with very different age structures than the total U.S. population. However, to the extent that analyses employ the same standard population for age adjustment, it will be possible to compare and interpret results across data systems and across data years. Using age-adjustment standards other than the 2000 Standard Population should be appropriately justified.

\section{References}

1. Shryock HS, Siegel JS, et al. The methods and materials of demography. Academic Press. New York. 1976.

2. Feinleib M, Zarate AO (eds). Reconsidering age adjustment procedures: Workshop Proceedings. Vital Health Stat 4(29). 1992.

3. Anderson RN, Rosenberg HM. Report of the Second Workshop on Age Adjustment. National Center for Health Statistics. Vital Health Stat 4(30). 1998.

4. Anderson RN, Rosenberg HM. Age standardization of death rates: Implementation of the year 2000 standard. National vital statistics reports; vol 47 no 3. Hyattsville, Maryland: National Center for Health Statistics. 1998. (http://www.cdc.gov/nchswww/products/pubs/pubd/nvsr/47pre/47-pre.htm)

5. Curtin LR, Klein RJ. Direct standardization (age-adjusted death rates). Health People Statistical Notes No. 6 (revised). March 1995.

6. U.S. Department of Health and Human Services. Healthy People 2010. 2nd ed. with understanding and improving health and objectives for improving health. 2 vols. Washington: U.S. Government Printing Office. 2000.

7. Shah BV, Barnwell BG, and Bieler GS. SUDAAN, Software for the statistical analysis of correlated data. SUDAAN User's Manual, Release 7.5. Research Triangle Park, NC. Research Triangle Institute. 1997. Additional information available at: http://www.rti.org/patents/sudaan/sudaan.html (Dec 2000).

8. Shalala DE. HHS policy for changing the population standard for age adjusting death rates. Memorandum from the Secretary. August 26, 1998.

9. National Center for Health Statistics. Health, United States, 1999, with health and aging chartbook. Hyattsville, Maryland. 1999.

(http://www.cdc.gov/nchswww/products/pubs/pubd/hus/hus.htm)

10. Day JC. Population projections of the United States by age, sex, race, and Hispanic origin: 1995 to 2050, U.S. Bureau of the Census, Current Population Reports, P25-1130, U.S. Government Printing Office, Washington. 1996. (http://www.census.gov/prod/1/pop/p25-1130/)

11. Department of Health and Human Services (DHHS). Tracking Healthy People 2010. Washington: U.S. Government Printing Office. 2000. 
Healthy People 2000

\section{Healthy People 2010}

Health Status Indicators for the Year 2000

Fall 1991

Winter 1991

Health Status Indicators: Definitions and National Data Spring 1992

Summer 1993 July 1993

March 1995

Revisions to Healthy People 2000 Baselines

Direct Standardization (Age-Adjusted Death Rates

Years of Healthy Life

Evaluating Public Health Data Systems: A Practical Approach

Monitoring Air Quality in Healthy People 2000

Health Status Indicators: Differentials by Race and Hispanic Origin

Operational Definitions for Year 2000 Objectives: Priority Area 20, Immunization and Infectious Diseases

Operational Definitions for Year 2000 Objectives: Priority Area 13, Oral Health

Healthy People 2000 Midcourse Revisions: A Compendium

Operational Definitions for Year 2000 Objectives: Priority Area 14, Maternal and Infant Health

Priority Data Needs: Sources of National, State, and Local-level Data and Data Collection Systems

Operational Definitions for Year 2000 Objectives: Priority Area 6, Mental Health and Mental Disorders

Operational Definitions for Year 2000 Objectives: Priority Area 21, Clinical Preventive Services

Operational Definitions for Year 2000 Objectives: Priority Area 1, Physical Activity and Fitness

Healthy People 2000: An Assessment Based on the Health Status Indicators for the United States and Each State
April 1995

June 1995

September 1995

September 1995

February 1997

May 1997

August 1997 December 1997

December 1997

February 1998

December 1998

December 1998

November 2000 

DEPARTMENT OF

HEALTH \& HUMAN SERVICES

FIRST CLASS MAIL

POSTAGE \& FEES PAID

$\mathrm{CDC} / \mathrm{NCHS}$

Centers for Disease Control and Prevention

PERMIT NO. G-284

6525 Belcrest Road

Hyattsville, Maryland 20782-2003

OFFICIAL BUSINESS

PENALTY FOR PRIVATE USE, $\$ 300$

To receive this publication regularly, contact

the National Center for Health Statistics by

calling 301-458-4636

E-mail: nchsquery@cdc.gov

Internet: www.cdc.gov/nchs/

\section{Suggested citation}

Klein RJ, Schoenborn CA. Age adjustment using the 2000 projected U.S. population. Healthy

People Statistical Notes, no. 20. Hyattsville,

Maryland: National Center for Health Statistics.

January 2001. 